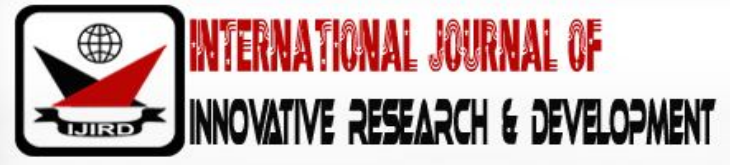

ISSN 2278 - 0211 (Online)

\section{A Review of Place Branding Strategy in City Planning}

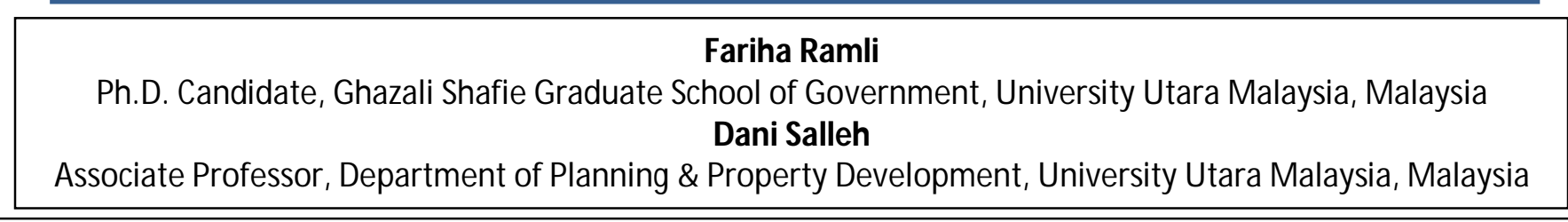

\begin{abstract}
:
Competitions between places in consequence to rapid development change the environments and the developments trend. This competition makes the place need to be better than their competitors. It made places development active, and the emphasis is being the perception of the place as the brand. The paper aims to explore the potential of place branding strategy as a mechanism in city planning. The paper provides an understanding of the place branding and its role in city planning. Place branding is a taken aspect of present development. It has expanded into an acceptable answer to the issue of conflict between the cities. Place branding is one of different practice to recover the position and image of the place or city.
\end{abstract}

Kevwords: Place brandinq, city planning, city manaqement

\section{Introduction}

Various places havedifferent image and tastebetween each other. In the progress of development has changed the physical environment and that bring in the changed of the image of place. The flooding of city construction has attack on the image and the place (Gordon \& Richardson, 2000). In Malaysia, place images have become a concern since 1970. The politicians and professionals constantly stressed the topic of Malaysian image through infrastructure build. According to Shuhana Sulaiman and Ahmad Bashri Shamsuddin (2001), in 1991, Federal Government announced that all capital state in the land must picture an identity by practising landscape components.

\section{Place Branding}

According to Kapferer (2012), brand is the memory and future of the product. The brand is the judgment of people on the product or business and which other visions of that (Handley, 2012). Accordingly, the product or business lies in the appreciation and confidence of a brand signature. In the perspective of place branding, branding is effective when place constantly produces concomitant modern of place life. The idea is in line with Gilmore (2002) that the nation continuously increased to the modern style, branding operating to benefit. Kavaratzis and Ashworth (2005) said that the branding fixates people judgments and vision to the products. Branding is necessary to whole idea of product (Kotler, 2000). Brand is an image and identity building. From the image and identity, 'non-user' started to know and identify the product.

In around the world, place branding publicly practised. Place branding is an innovative perspective on communication and develops the marketing image of the city in a diversity of styles to modify the visible image and the brand image (Rehan, 2013). According to VanAuken (2014), place branding is complex and exciting. Ritchie and Ritchie (1998) portrayed a place brand by focusing on the components and capabilities. It helps to consolidate and grow pleasurable thoughts of the place activity (Ritchie \& Ritchie, 1998).

\section{City Planning}

Lately, city planning was seen as a crucial procedure (Wiechmann, 2008). The public debate on the city planning system has accentuated on the complexities and the feature of spatial changes by using a global standard of objectivity, which begins in positivism. The city planning starts influence in the early 1990s. It looked to suggest an exit door for the city which was dropped by conservative planning (Balducci, Fedeli, \& Pasqui, 2011). Healey (1997) said the 'swing methodology' in regional planning is an answer to the weaknesses of an incremental planning procedure by experiments. These days, the focus is the most challenging missions of spatial (city and regional) administration (Wiechmann, 2008).

The end goal of city planning is to identify and improve the volatility of in city developments. The critical of city planning has resided at the center crossing within the need for meaningful image and prognosticating the inconceivability of 
crush components. Nevertheless, importance of planning that started at 1950s was ascribed to the necessity for immediately growing and progressing and the need of dealing with their shares when the prospect itself issued indefinite (Kaufman \& Jacobs, 1987). Also, Albrechts (2004) said that the aspects of the importance of planning indicate to the reformations in the United States and Europe. In the mid-1970s, the colonial administration in the United States progressively inspired the effective planning after the curving changes recognised as "life crises, statistic changes, evolving values, the unpredictable economy" (Albrechts \&Broeck, 2004).

\section{Place Image}

The city image is reliable was a continuous experiment and continually "under construction." Calvino (1997) in the "Undetectable Cities" described city spaces as creative places and formations of playfield for intelligent imaging the city. Pike (1981) stated that "the existing of the city not in place, but in story time." Thus, the place image is highlighted by the fantasies, dreams, desires, and myths. Raban (1974) said a city resided on the maps, in perspicacity, and talk. In the absence of the story, the creative potential of urban folks is remaining secret. The paper suggested it regardson the game between the image and the city.That take in more about the image through the city than about the city through the image. That is the reason such a large number of image of the city let us know so minimal about the city itself.

According to Lynch (1960), city image has three segments which are structure, personality, and significance. These segments classify the imaging capability, which is "the quality of a physical object that gives the possibility of making a solid picture by the eyewitness" (Lynch, 1960). That standard is driven by the combination of segments such as shading and spatial link in the image. However, the influences of physical position as a "free variable" also form on the "social value of a place" (Lynch, 1960). Andreoli (1996) portrayed that city image forms by the building. Place image is delivered in the structure in which it was a big group of interests which is denotative and demonstrative levels of implication trapped and new types of city mythologies, mythography and place- image develop.

\section{Intertwining Place Branding and City Planning}

The place branding unites the diversity of the issues and problems to the study in city management and public participation in planning (Van Assche \& Lo, 2011). The authority is a group of managing the direction, and it is not only restricted to the specialist. As stated by Jessop (1997), it was the social and spatial procedures intentionally arranged in points of dependence. It needs to be noted that city planning is a policy-making process, operating with multi-partner of stakeholders, and produce strategies based on skill and logical (Allmendinger\& Haughton, 2009; Van Assche, Beunen, $\&$ Duineveld, 2012). The process of city planning can be substantive, procedural, plan to form, administer run, led by political group, and the spatial type of financial and legal (Van Assche et al., 2012). Also, city planning is much about the method as it is regarding institutional guidelines (Albrechts \& Broeck, 2004).

What encourage transpired of place branding in the city planning? Albrechts (2013) claim spatial planning is prepared to take an important move in its direction culturally and financially to increase the place image by adopting various devices. Some European countries practice planning tools, such as building control and zoning in practising the place branding. Also ,important to understand how a brand of place can build imaginative and passionate connections with the place. The paper discusses upon the place branding as an idea where the method of thought must meet to the idea of the brand needs of the place, along with the parties involved, and the reason of branding methods use at the place. It is also necessary to recognise how a brand of place can create mental and passionate relationships with the place. The use of physical characteristics is to recognise whether the place needs to be produced, improve, pressure, or stay away from place branding approach (Ashworth \& Kavaratzis, 2010). Drawing on this, Balducci, Fedeli, and Pasqui (2011) in designed the concept of place branding as an instrument in city planning and considered place branding as the tool in city planning. Place branding in city planning may encourage to construct more combine place brand with components of the place. Besides, the study of city planning for branding activities can prevent damaging factor. The application of place branding as a practice in city planning is fascinating to corporate interests and profit proceeding. The strategy of place branding is to meet the community need nearly, and this is not the latest procedure.

Place branding attempts to catch on the more useful aspect of the physical component where image, assets, condition, and personalities are important to the place improvement. However, it is important to enable the stakeholders to be connected to a place and become agents of the combination. Also, this understands authority as the primary authority in the process of place branding. Also, flexibility and versatility of place help that the unique characteristics of city planning that should consider when drafting the place branding strategy. Healey (2009) said the ventures of the real framework is diminishing the wrong planning acts; open the doors for advancing financial; restraining exposures of a threat to the natural and working out on historic preservation.

That important to recall that city planning own some tools as city development strategies, development plans, and urban designs strategy. However, the multifaceted of place landscape and the difficulties face now demand the alternative procedure and innovative tools. According to Kavaratzis (2010), place branding is a definite method to growth activities of the place for a global position, dynamic shape, and good financial. Additionally, Pasquinelli (2010) said, place branding is related to the economic improvement activity. Then, it could be an alternative medium that city authority is seeking for. In both city planning and place branding fields, characterising a clear image of a place is quintessential. This is the dream of a 
place which areto recognise what the place is and the long-term plans for the place. The dream comes together with a comprehensive procedure, budgetary, human resources, and projects. Ashworth and Kavaratzis (2010) said, to fill the 'dream', the place should use the creative ideas of place activities as a 'formula.' To do the idea, it need explore the questions of 'why' and 'how.'

The 'why' is the place must change in reaction to the challenges of social, financial, and identical improvement bearing. Seeing place branding in the main of city planning could efficiently pull the talents interest, develop the quality, grow supplies and character, and called some of the readability on the specialist (that is, the soul of place). These can achieve by getting to potential tenants, specialists, investors, visitors, labourers, and other place roles (the 'how'). Putting place branding as city planning tool could enhance the commitment of place participants by fixing up their view on the political and economical through "zooming in" on places needs, quality, and assets. Albrechts (2010) claimed that a principal planning practice ought to remove from the social and political critique of the place to which a definite place or society is engaged.

Joining place branding in the city planning exercises could support a meaningful resolution. For example, repositioning, reorientation, and turning the image of place forward with the raised volume of social and financial improvement. It is just same a popular catchword, 'small steps big changes.' Additionally, city planning implies to plan mutually with citizens and build efforts for their singular accomplishment. Ashworth and Kavaratzis (2010) stated the people change a unique part in guaranteeing the completion of place branding exercises. Moreover, Therkelsen, Halkier, and Jensen (2010) noticed the opportunity to utilise place branding as a public participation instrument, yet that demands more effort and commitment than nearby from the experts to put into it. Thus, if individuals feel like a part of the place branding process, they probably understand the place in general.

The chance to use place branding as an instrument, yet that demands more work and engagement than regularly by the experts to put into (Therkelsen et al., 2010). Hence, if people think like a member of the place branding activities, they apparently know the place in broad. The desire of experts is constant to practice branding as a powerful, smart, modest, and "dreamlike composition" in contact to put the brand to the grapples and weak place (Ashworth \& Kavaratzis, 2010).

The paper emphasises that the 'ideal strategy' of city planning that ever exists is place branding benefits in physical exercises. Nevertheless, when managing the standard exercise, it relies on the place. Amongst concerns that need to be looked at is whether the 'place' has previously has a brand, and how stable it is. Place branding as a mechanism of city planning could work and create a partnership by setting the place personality and by highlighting the assets and congregating in planning exercise. These advantages are convenient to increasing the place reputation and image. Those benefits are accessible to improving the place image and place reputation. According to Zenker and Braun (2010), place branding work should be signified by the guidelines, communication, features, qualities, and the culture of the society and stakeholders. By that, it is necessary to set up a right approach for the production of the dynamic practice of place branding.

\section{The Potential of Place Branding Strategy in City Planning}

Brands can be defined as goods or services. It is blended with its identity, name, image, and respect. It is subject to interpretation by the users itself which are doing sections. The sections are formed of its image, identity, equity, and desire. Anhold (2007) said that there is plenty of advantages from branding. The benefits are that branding should be as based on Anholt (2007) are:

- Open domestic venture on national identity and community goals;

- An environment where difference is appreciated and felt;

- Soaring valuable in worldwide exhibitions offering;

- More efficient efficiency in investment promotion;

- More useful in tourism and business travel advertising;

- A stronger "country of origin effect" for exporters of goods and services;

- Excellent perception in the global media;

- More straightforward acceptance into regional and international groups and associations; and,

- Richer cultural connections with other regions and countries.

Those benefits can be obtained if the three important components of what place branding is being understood. First, the brand can bring investors, talent, users, tourists, recognition, and admiration. Second components are confident and robust brand can be attached to the activities. The last one is the brand has potential in order, as it can help corporations within different crowds, which might usually argue, to achieve a purpose. Sequentially the thought to make those profits is a complexresponsible for the place. The more businesses, the more meaningful profits will be transferred,and the economy will increase. How ever, those earnings commitments need be applied towards additional improvement.

Other advantages, which can be obtained from place branding, include more significant investment, profits, and export advantages. The investment to the place shows the benefits of exporting. The advantage from the altruism of place can be delivered through branding by containing strong brand and great reliability in activities. Users are more sensitive to the products or businesses if they are connected with a positive place image or reputation. Thus, it encourages the businesses to export their goods and enter other markets, if they are ready to join and understand their cooperation with the values and purposes of place. Still, branding demands to go into the creative method of communicating with the stakeholders. The 
creative process involves the parts of planning, communicating, designing, and, and ideally connects the users with the product and association.

\section{Conclusion}

In branding, perspective is everything. The engagement with crowds put roles respectively and having help in building brand is track ahead of successful approach. Place branding may look like tiny parts of procedure, but when performing that in a position of small gains is a more appropriate approach than placing it all in one box. In such manner, place branding hashad function of delivering something to everyone. However, it only results if everyone works their part. Place branding in city planning improves the important relationship between the place users.

\section{Directions for Future Research}

To study result of strategies and approach in the long-term to users in more in-depth perspectives of economic, social, and environmental. That study demands a continued duration of the study as in five years, ten years, or more. The findings that provide sustainability and influence of procedures and approach to users to be classified.

\section{References}

i. Albrechts, L. (2010). How to enhance creativity, diversity and sustainability in spatial planning: strategic planning revisited. In Making Strategies in Spatial Planning (pp. 3-25). Springer, Dordrecht.

ii. Albrechts, L. (2013). Reframing strategic spatial planning by using a coproduction perspective. Planning theory, 12(1), 46-63.

iii. Albrechts, L., \& Broeck, J. V. D. (2004). From discourse to facts: the case of the ROM Project in Ghent, Belgium. Town Planning Review, 75(2), 127-150.

iv. Allmendinger, P., \& Haughton, G. (2009). Soft spaces, fuzzy boundaries, and metagovernance: the new spatial planning in the Thames Gateway. Environment and Planning A, 41(3), 617-633.

v. Andreoli, E. (1996) The Visible Cities of São Paulo. In: I. Borden, J. Kerr, A. Pivaro, J. Rendell (eds.), Strangely Familiar: Narratives of Architecture in the City, London: Routledge, pp. 62-66

vi. Anholt, S. (2007). Competitive identity: The new brand management for nations, cities and regions. Journal of Brand Management, 14(6), 474-475.

vii. Ashworth, G., \& Kavaratzis, M. (Eds.). (2010). Towards effective place brand management: Branding European cities and regions. Edward Elgar Publishing.

viii. Balducci, A. , Fedeli, V. and Pasqui, G. (2011), Strategic Planning for Contemporary Urban Regions: City of Cities: A Project for Milan , Ashgate, Surrey.

ix. Balducci, A. , Fedeli, V. and Pasqui, G. (2011), Strategic Planning for Contemporary Urban Regions: City of Cities: A Project for Milan , Ashgate, Surrey.

x. Calvino, I. (1997) Invisible Cities, London: Vintage.

xi. Gilmore, F. (2002). Branding for success. Destination branding: Creating the unique destination proposition, 57-65.

xii. Gordon, P., \& Richardson, H. W. (2000). Defending suburban sprawl. Public interest, (139), 65.

xiii. Handley, A., \& Chapman, C. C. (2012). Content rules: how to create killer blogs, podcasts, videos, ebooks, webinars (and more) that engage customers and ignite your business (Vol. 13). John Wiley \& Sons.

xiv. Healey, P. (1997). Making strategic spatial plans: Innovation in Europe. Psychology Press.

xv. Healey, P. (2009). City regions and place development. Regional Studies, 43(6), 831-843.

xvi. Jessop, B. (1997). The entrepreneurial city: re-imaging localities, redesigning economic governance, or restructuring capital. Transforming cities: Contested governance and new spatial divisions, 46, $28-41$.

xvii. Kapferer, J., N. (1997) Strategic Brand Management: Creating and Sustaining Brand Equity Long Term, London: Kogan Page

xviii. Kaufman, J. L., \& Jacobs, H. M. (1987). A public planning perspective on strategic planning. Journal of the American Planning Association, 53(1), 23-33.

xix. Kavaratzis, M. (2010). Is corporate branding relevant to places. Towards Effective Place Brand Management-Branding European Cities and Regions. Cheltenham, UK: Edward Elgar Publishing, 36-48.

xx. Kavaratzis, M., \& Ashworth, G. J. (2005). City branding: an effective assertion of identity or a transitory marketing trick?. Tijdschrift voor economische en sociale geografie, 96(5), 506.

xxi. Kotler, P. (2000) Marketing Management. The Millennium Edition. Upper Saddle River, Prentice Hall.

xxii. Lefebvre, H. (1991) The Production of Space, Cambridge MA: Blackwell

xxiii. Lynch, K. (1960). The image of the city. Cambridge: MIT Press

xxiv. Pasquinelli, C. (2010). The limits of place branding for local development: The case of Tuscany and the Arnovalley brand. Local Economy, 25(7), 558-572.

xxv. Pike, B. (1981) The Image Of The City In Modern Literature, Princeton; Guildford: Princeton University Press.

xxvi. Raban, J. (1974) Soft City, London: Hamish Hamilton. 
xxvii. Rehan, R., M. (2013). Sustainable streetscape as an effective tool in sustainable urban design. HBRCJournal, 9(2), 173186.

xxviii. Ritchie, J., R., B. \& Ritchie, R., J., B. (1998) The Branding of Tourism Des-tinations: Past Achievements and Future Challenges. In: Conference Proceedings of the Annual Congress of the International Association of Scientific Experts in Tourism (AIEST), Marrakesh: Morocco, 1 September, pp. 89-116

xxix. Shuhana Sulaiman \& Ahmad Bashri Shamsuddin (2001). The Vanishing streets in the Malaysian urbanscape. In Public Places in Asia Pacific Cities (pp. 137-149). Springer Netherlands.

xxx. Therkelsen, A., Halkier, H., \& Jensen, O. B. (2010). Branding Aalborg: Building Community or Selling Plance?. In Towards Effective Plance Brand Management (pp. 136-55). Edward Elgar Publishing, Incorporated.

xxxi. Van Assche, K., \& Lo, M. C. (2011). Planning, preservation and place branding: A tale of sharing assets and narratives. Place Branding and Public Diplomacy, 7(2), 116-126.

xxxii. Van Assche, K., Beunen, R., \& Duineveld, M. (2012). Performing success and failure in governance: Dutch planning experiences. Public Administration, 90(3), 567-581.

xxxiii. VanAuken, B. (2014). Brand Aid: A Quick Reference Guide to Solving Your Branding Problems and Strengthening Your Market Position. AMACOM Div American Mgmt Assn.

xxxiv. Wiechmann, T. (2008). Errors expected-aligning urban strategy with demographic uncertainty in shrinking cities. International Planning Studies, 13(4), 431-446.

xxxv. Zenker, S., \& Braun, E. (2010, June). Branding a city-a conceptual approach for place branding and place brand management. In 39th European Marketing Academy Conference, Copenhagen, Denmark (pp. 1-4). 